\title{
СЕМАНТИКО-СТИЛИСТИЧЕСКИЕ ТРАНСФОРМАЦИИ В РУССКОМ ЛИТЕРАТУРНОМ ЯЗЫКЕ ХVIII-ХХІ СТОЛЕТИЙ
}

\author{
SEMANTIC AND STYLISTIC TRANSFORMATIONS \\ IN RUSSIAN LITERARY LANGUAGE \\ FROM THE $18^{\text {TH }}$ TO THE $21^{\text {ST }}$ CENTURIES
}

\author{
ТАТЬЯНА НИКОЛАЕВА, АННА ШИШОВА
}

\begin{abstract}
Investigating the semantic and stylistic transformations of the meaningful language units functioning in a given epoch allows us to show the internal regularities of their evolution, their systemic nature, and conditionality on factors of a historically cultural character. Realizating the semantic potential of a word capable of the associative rethinking plays an important role in the organization of modern vocabulary.

Татьяна Николаева, Казанский университет, Казань - Россия, i.tarchevsky@mail.ru Анна Шишова, Казанский университет, Казань - Россия, bowari@yandex.ru
\end{abstract}

Изменения в семантике и стилистической маркированности, приведшие к появлению новообразований, всегда исторически обусловленный процесс, который заслуживает особого изучения с учетом того, что в разные периоды языковой эволюции он проявлял себя наиболее ярко и значимо в разных лексических пластах: 1) XVIII - начало XIX вв. - преобразование отношений между церковнославянскими и исконно русскими элементами, способствующее метафоризации и, как следствие, появлению новых синонимических рядов; 2) XIX-XX вв. - адаптация заимствований, которые, подвергаясь переосмыслению, активно участвуют в процессе складывания общеязыковой нормы; 3) XX-XXI вв. - демократизация, одним из проявлений которой являются семантико-стилистические преобразования ненормативной лексики.

1) В XVIII столетии складываются новые соотношения в стилистической системе литературного языка, которые устанавливаются в результате утраты маркированности „высокого”, связанной с распадом церковно-книжного стиля, что привело к семантическим преобразованиям лексем и формированию новых синонимов. Сыграли свою роль и потребности в номинациях, соответствующих действительности, вызванных бурным развитием социально-экономической, общественной и культурной жизни. 
Особенно выразительны были глаголы, способные образовывать длинные синонимические ряды, например: восстать - воспрянуть - возбудить - пробудить, где первые три глагола оказываются объединенными церковнославянской приставкой воз- / Boc-, сыгравшей роль стилистического маркиратора. На раннем этапе, как свидетельствует Словарь русского языка XI-XVII вb. ${ }^{1}$, указанные глаголы были объединены общностью исходного значения - 'будить от сна, поднять (с постели)'. В эпоху Киевской Руси глагол восстати (встати) уже функционировал с трансформированным значением 'выступить, подняться против кого-л., на кого-л.'” „Вставщее (здесь и далее курсив мой - Т. Н.) новгородци избиша варягы" (Лавр. ^ет., 140, 1201). По аналогии с восстати глагол возбудити в XVI веке стал обозначать 'побудить к каким-либо действиям'. Семантическая адекватность исходного значения всех четырех глаголов, входящих в синонимический ряд, способствовала их сближению, определяя в глаголе воспрянуть новое значение. Однако этот процесс начался только в XVIII веке. Своеобразным переходом к приобретению глаголом воспрянуть новой семантики явилось использование М.В. Ломоносовым его фонетического варианта в известной Оде на день восшествия на престол императрицы Елизаветы Петровны: „На трон взошла Петрова дщерь... О утра час благословенный! Мы в скорбной темноте заснули. Но в радости от сна вспрянули". Яркую публицистическую окраску глагол Воспрянуть приобретет в творчестве А.С. Пушкина - „Россия Вспрянет ото сна”, а впоследствии - в известном пролетарском гимне „Воспрянет род людской”.

Глагол пробудить, составляющий древнюю семантическую параллель глаголам синонимичного ряда, по аналогии с ними, с конца XVIII века развивает новое, вторичное значение 'вызывать чувства, мысли, порождать, усиливать'. „Бедствия пробуждают в душе множество прекрасных свойств” (К.Н. Батюшков), „Восторги дух мой пробудили” (Е.А. Боратынский).

Новое звучание глагольных образований Восстать - воспрянуть - возбудить - пробудить было реализовано в жанре революционной публицистики и в гражданской лирике во второй половине XIX века.

B XX-XXI вв. наблюдается семантический распад синонимического ряда слов. Со значением призыва, побуждения к гражданским действиям употребляется лишь глагол восстать, хотя сегодня его можно отнести к архаизмам; пережив вторичную метафоризацию, возбудить ныне используется для передачи нервного и физиологического состояния, кроме того, в качестве члена неразрывного словосочетания - в юриспруденции: возбудить дело; воспрянуть функционирует в со-

1 Словарь русского языка XI-XVII въ., „Наука”, Москва 1975. 
четании с существительным $\partial y x$ в творительном падеже как средство создания иронии; малоупотребительный глагол пробудить помечен в современных словарях как „устаревший” 2 .

2) Семантико-стилистическую трансформацию, приведшую к появлению новообразований, целесообразно проиллюстрировать на примере заимствований, которые проходили адаптацию на русской почве в XVIII-XIX веках. Это был процесс, отличающийся исключительной неадекватностью: с одной стороны, засилье французского, с другой - стремление избавиться от излишних иностранных слов. В этой связи необходимо вспомнить декрет, изданный при Павле I в 1797 году, „Об изъятии из употребления некоторых слов и замене их другими”, в котором вместо лексемы сержант рекомендовалось употреблять унтер-офииер, вместо граждане - жители или обыватели, вместо приверженность - привязанность, усердие, лексему общество предлагалось вообще изъять из обращения.

Лексема nampuom (фp. patriote) встречается впервые в эпоху Петра I в значении 'сын отечества': „Того ради побужден некоторый верный nатриот из Российского народа... сие рассуждение на свет выдать" ${ }^{3}$. В первой половине XIX века, наряду с сохранением основного значения, лексема приобретает специализированную семантику: 'отечестволюбец, любитель отечества, рачитель, ревнитель о пользе отечества' которая ассоциируется с революционными идеями о свободном человеке, гражданине, что находит свое отражение в творческом наследии А.Н. Радищева и декабристов. К 20-м годам XIX века лексема получает больший объем, обозначая в реакционных кругах русского общества лиц либеральных взглядов, убеждений: „Банкротство дворянства, продажность правосудия и крепостное право - вот элементы, которые русские патриоты считают возможным использовать в подходящий момент, чтобы возбудить волнения в пользу конституции", - так пишет директор канцелярии III отделения М.Я. фон Фок в конце 20-х годов 5 . Именно с этой семантикой она используется А.С. Пушкиным в Евгении Онегине: „Скажите, чем он возвратился? Что нам представит он пока? Чем ныне явится? Мельмотом, Космополитом, патриотом, Гарольдом, квакером, ханжой, Иль маской щегольнет иной?". Однако у А.С. Пушкина патриот используется и с окраской иронии, сарказма:

\footnotetext{
2 Словарь русского языка $b$ 4-x mm., Институт русского языка АН СССР. „Русский язык", Москва 1981-1984.

${ }^{3}$ Н.А. С м и р н о в, Словарь иностранных слов, вошедших в русский язык 8 Петровскую эпоху, „ОРЯС АН” 1910, т. 88, № 2, с. 222.

${ }^{4}$ Н. Я н о в с к и й, Новый словотолкователь, по азбучному порядку расположенный, ч. 3, Санкт-Петербург 1803-1806, с. 285.

5 В. О р л о в, Русские просветители, Москва 1961, с. 300.
} 
„Некоторые люди не заботятся ни о славе, ни о бедствиях отечества... и со всем тем почитают себя патриотами, потому что любят ботвинью и что дети их бегают в красной рубашке" ${ }^{\prime \prime}$. Подобное стилистическое маркирование способствовало тому, что именно в пушкинскую эпоху появляются сочетания, в которых патриот сопровождается эмоциональным оценочным атрибутом с отрицательной экспрессией: самозваный, невпопад усердный, къасной, восторженный. Впоследствии подобные сочетания использовал в публицистике В.Г. Белинский, и это обстоятельство сыграло свою роль в приобретении словом патриот в конце XIX столетия негативной окраски. Во всяком случае в словарях эту лексему ставили в кавычки в знак неприятия ее с позитивным значением. Об этом писал И.А. Бодуэн де Куртенэ: „Теперь принято различать патриота без кавычек и патриота в кавычках". В Предисловии к Словарю Вл. Даля он замечает: "Слова патриот, патриотизм получили огромный и карательный оттенок”7. У А.М. Горького: „Переезжайте в Петербург. У меня там есть хороший знакомый, видный адвокат, неославянофил, т. е. империалист, патриот, немножко идиот" (Жизнь Клима Самгина). В настоящее время патриот используется только с положительной коннотацией.

Еще более тернистый путь прошла лексема революиия, прежде чем приобрести гражданское звучание. Малоизвестен тот факт, что первоначально она адаптировалась на русской почве, обозначая астрономическое понятие - „течение звезд”, и была запрещена к употреблению императором Павлом I в специальном Указе, адресованном Академии наук. В конце XVIII - начале XIX столетий слово пережило семантическую трансформацию и могло обозначать как „внезапную перемену" в правлении какого-то народа"8, так и вообще переворот в любой сфере человеческой деятельности. Именно такой семантикой наделяет его М.Фасмер, возводя к латинскому revolutio (через польский rewolucja) ${ }^{9}$. Насколько революция трудно адаптировалась на русской почве с указанным значением, свидетельствует следующее высказывание А.С. Шишкова: „Никогда в Российском языке доселе не означало оно сего понятия (nереворот - Т. Н.) ${ }^{10}$.

${ }_{6}$ Словарь языка Пушкина в 4-x mm., Институт языкознания АН СССР, Москва 1956-1959.

7 И.А. Б о д у э н д е К у р т е н э, Предисловие к 3-му изданию „Словаря живаго великорусского языка" Вл. Даля, Москва 1903, с. 4.

8 Н. Я н о в с к и й, указ. соч., с. 129.

9 М. Ф а с м е р, Этимологический словарь русского языка 84 mm., „Прогресс", Москва 1964-1973.

10 А.С. Ш и ш к о в, Рассуждение о старом и новом слоге Российского языка, Санкт-Петербург 1803, с. 184-185. 
Процесс семантико-стилистической трансформации заимствований активизировался в начале XX века. Так, в Толковом словаре военных слоһ, вышедшем в Праге в 1914 году, французское (из греческого) дема202 традиционно трактуется как 'название людей в древней Греции, которые держали народ в своих руках благодаря своему личному влиянию и силе слова'. Однако еще в 80-е годы прошлого столетия словари фиксируют новое значение: 'революционер, представитель народной партии'11. В Словаре Даля дается более яркая эмоционально-экспрессивная окраска: 'крайний демократ, добивающийся власти во имя народа, тайный возмутитель, поборник безначалия, желающий ниспровергнуть порядок управления' 12 . Негативную оценочность слово приобретает в практике партийной пропаганды, для которой были характерны ложь, извращение фактов, бессмысленные априорные рассуждения, не основанные на конкретных данных, что послужило причиной для вторичной переквалификации лексемы, отсюда - ее современная трактовка: 'человек, занимающийся лживыми обещаниями, искажением подлинной сути событий, рассуждениями, построенными на одностороннем осмыслении' 13 .

Подверглась преобразованиям и лексема будировать, которая из-за фонетического сходства с будить начинает использоваться не с французским значением 'дуться, сердиться', а 'будить, пробуждать к действиям, протесту'14. Подобное функционирование не стало нормой, чему, вероятно, способствовало высказывание В.И. Ленина, направленное против неправильного толкования этого слова в статье „Об очистке русского языка”: „Употребляют слово «будировать» в смысле возбуждать, тормошить, будить. Но французское слово «bouder» (будэ) значит сердиться, дуться..."15. Однако в современной речевой практике достаточно широко распространено его использование с несвойственным ему, ошибочным значением.

Творческая интеллигенция в эмиграции активно выступала против использования иностранных слов, в том числе - в семантизированном варианте, и предлагала их переводы на русский язык: телефон - дальносказ, кондитерская - сластежная, вокзал - стан, адьютант - попыхач, кроссворд - крестословица и др. Любопытно, что слово интелиигент, зафиксированное в Словаре Даля16 со значением 'умственно раз-

${ }^{11}$ Н. Я н о в с к и й, указ. соч., с. 20.

12 В. Д а л ь, Толковый словарь великорусского языка, 3-е изд., Москва 1903-1905.

13 Словарь русского языка в 4-х тm., указ. соч.

14 Б. Л и н с к и й, Политический словарь, Санкт-Петербург 1906.

15 В.И. Л е н и н, Об очистке русского языка, [в]: его же, Полное собрание сочинений, т. 40, Москва 1958, с. 49.

16 В. Д а л ь, указ. соч. 
витой человек', не воспринималось в среде дореволюционных государственных деятелей. Так, С.Ю. Витте цитирует высказывание государя Николая II: „Как мне противно это слово (интелигент - Т. Н.), следует приказать Академии наук вычеркнуть его из словаря" 17.

3) Процесс демократизации русского литературного языка, начиная с XX века, наиболее ярко проявлялся в проникновении нейтральных слов в словарный состав представителей различных социальных групп, которые подверглись переосмыслению. В 1908 году появился Словарь В.Ф. Трахтенберга „Блатная музыка" („воровской жаргон”) под редакцией Бодуэна де Куртенэ. В предисловии к Словарю ученый высказал мысль о необходимости изучения „тайного языка”, „жаргона тюрьмы”, или „блатной музыки”, составляющей „достоверный материал для психолога, для этолога (теоретика или историка этики или нравственности), для юриста, для исследователя народной словесности и прежде всего для лингвиста или языковеда" 18 .

На жаргоне мошенников денежные купюры назывались барашкамu, у шулеров выигранные деньги - игрушками, а находящиеся еще у владельца - „пассажира" - кровью. Отсюда пустить кровь - обыграть, пошиа кровь носом - партнер начал расплачиваться. Кредитные билеты разного достоинства: рублевый - кенарь, иногда - канарейка, трехрублевый - попугай, пятирублевый - петух, десяти- - карась (по красному цвету), тысяча - коса.

В Словаре - множество семантически преобразованных, ранее нейтральных слов, ставших новообразованиями и приобретших эмоционально-стилистическую маркированность: жулик - ножик, чердачок - жилетный карман, собачка - висячий замок, подсолнух - золотые часы, колёса - сапоги, борзой - предатель, шпана - коренное тюремное население (возможно, от шпанка - порода овец, которые в стаде кажутся серыми и однообразными). Этот список пополняет ряд глаголов и глагольных сочетаний: капать - доносить, загнать в бутылку - раздразнить, вывести из себя, дать винта - убежать, арапа заправıять - не платить долгов, заливать - врать, завести волынку - выразить протест, загнать - продать. Как видим, некоторые из них активно функционируют и в современном русском литературном языке в качестве эмоционально окрашенных, ставших нейтральными лексем.

Снятие запретов, свобода слова в сегодняшней коммуникации привели к тому, что жаргонная лексика беспрепятственно появляется в статьях на серьезные экономические, общественно-политические

\footnotetext{
1994, c. 27.

18 И.А. Б о д у э н де К у р т е н э, Предисловие к Словарю В.Ф. Трахтенберга „Блатная музыка", Санкт-Петербург 1908.
}

${ }_{17}$ С.Ю. В и т т е, Воспоминания. Царствование Николая II, т. 2, Скиф Алекс, Москва 
темы, в материалах о политических лидерах и представителях власти. Со стороны газет на читателя обрушиваются ненормативные лексемы с целью подвергнуть критике то или иное явление, показать недостатки нашей действительности. Это - бабло, бабки, тусовка, прикольно, засветиться, халявщик, понтоваться, клёвый, барыга, баланда, легавый, сходняк, жулик, ^ох, бакланить и другие, зафиксированные в современных словарях с пометой „разговорное”. Тем самым они демонстрируют процесс, обратный тому, который был характерен для прежних эпох: происходит нейтрализация жаргонизмов, арготизмов, эвфемизмов и переход их в разряд нормативных образований, тем самым пополняется и обогащается словарный запас литературного языка XX-XXI вв. ${ }^{19}$ Указанную тенденцию подтверждают данные лексиконов В.М. Мокиенко ${ }^{20}$. Ценность их в том, что словарные статьи сопровождаются основательными этимологическими изысканиями и комментариями исторического характера. Среди действующих новообразований баптист - бабник, тюльпан - глупый, ограниченный человек, сверхурочница - замужняя проститутка, илифовать - ласкать женщину, кукурузник - гомосексуалист.

Историко-культурологический подход к исследованию семантико-стилистических трансформаций убеждает в том, что реализация семантического потенциала слова, способного к ассоциативному переосмыслению, метафоризации, ярко проявляла себя в разные периоды формирования и становления русского литературного языка в различных пластах лексики и сыграла чрезвычайно важную роль в организации современного словарного фонда.

\section{Библиография}

Б о д у э н де К у р т е н э И.А., Предисловие к Словарю В.Ф. Трахтенберга „Блатная музыка", Санкт-Петербург 1908.

Б о д у э н де К у р т е н э И.А., Предисловие к 3-му изданию „Словаря живаго великорусского языка" Вл. Даля, Москва 1903.

В и т т е С.Ю., Воспоминания. Царствование Николая II, т. 2, Скиф Алекс, Москва 1994.

Д а ль в В., Толковый словарь великорусского языка, 3-е изд., Москва 1903-1905.

Л е н и н В.И., Об очистке русского языка, [в]: его же, Полное собрание сочинений, т. 40, Москва 1958.

Л и н с к и й Б., Политический словарь, Санкт-Петербург 1906.

19 Г.Н. С к л я р е в с к а я, Толковый словарь русского языка конца ХХ века, Институт лингвистических исследований РАН, Санкт-Петербург 1998.

20 В.М. М о к и е н к о, Словарь русской бранной лексики, Dieter Lenz Verlag, Berlin 1995; его же, Словарь русской брани, Норинт, Санкт-Петербург 2003. 
М о к и е н к о В.М., Словарь русской бранной лексики, Dieter Lenz Verlag, Berlin 1995.

М о к и е н к о В.М., Словарь русской брани, Норинт, Санкт-Петербург 2003.

О р л о в В., Русские просветители, Москва 1961.

С к л я р е в с к а я Г.Н., Толковый словарь русского языка конца ХХ века, Институт лингвистических исследований РАН, Санкт-Петербург 1998.

Словарь русского языка XI-XVII вb., „Наука”, Москва 1975.

Словарь русского языка в 4-х тm., Институт русского языка АН СССР, „Русский язык”, Москва 1981-1984.

Словарь языка Пушкина 8 4-х тm., Институт языкознания АН СССР, Москва 19561959.

С м и р н о в Н.А., Словарь иностранных слов, вошедших в русский язык в Петровскую эnоxy, „ОРЯС $\mathrm{AH}^{\prime \prime} 1910$, т. 88, № 2, с. 222.

Ф а с м е р М., Этимологический словарь русского языка в 4 mm., „Прогресс", Москва 1964-1973.

Ш и ш к о в А.С., Рассуждение о старом и новом слоге Российского языка, Санкт-Петербург 1803.

Я н о в с к и й Н., Новый словотолкователь, по азбучному порядку расположенный, ч. 3, Санкт-Петербург 1803-1806. 